DOI https://doi.org/10.18551/rjoas.2016-12.19

\title{
WORKING MOTIVATION AS MEDIATING VARIABLE FOR THE INFLUENCE OF SPIRITUAL QUOTIENT TOWARDS WORKING PERFORMANCE: A STUDY IN THE REGIONAL SECRETARY OF PUNCAK JAYA
}

\author{
Nuhujanan Romualdus Philippus*, Troeno Eka Afnan, Noermijati, Sudiro Achmad \\ Faculty of Economics and Business, University of Brawijaya, Indonesia
}

*E-mail: nuhujanan12rp@gmail.com

\begin{abstract}
Spiritual quotient is an important element for an individual to achieve self-actualization. An individual who understands his or her talent and potentiality is creative, visionary and flexible. Such individual has strong motivation to improve his/her performance. The purpose of the study was to analyze the influence of spiritual quotient towards working performance that was mediated by working motivation. The subjects were 89 employees working in the Regional Secretary of Puncak Jaya. The population became the samples in the study. The data collection technique was distributing questionnaire while the data analysis method was the Partially Least Square (PLS). The findings were spiritual quotient was positive but did not influence working performance. Working motivation had direct influence towards working performance. Therefore, working motivation was needed in order that spiritual quotient could increase working motivation. In other words, the role of working motivation towards the influence of spiritual quotient towards working motivation of the employees in the Regional Secretary of Puncak Jaya, Papua was as full mediation.
\end{abstract}

\section{KEY WORDS}

Spiritual quotient, working motivation, and working performance.

Working performance has become an issue for the management of both public and private institutions. Working performance has always been a serious concern of the public and private institutions because it facilitates them in achieving their goals.

Performance that is related to human resources has been widely discussed. In the globalization, competent human resources are the key for public and private institutions to survive the global competition and achieve goals of their institutions. Human resources is a central factor in the management of an organization. Human resources are needed in order to run the management smoothly and effectively, one that pays attention to the existing rules and regulations, in order to improve the performance and achieve the goals of the institutions.

In achieving their goals, an institution needs individuals with four types of intelligence namely Intellectual Intelligence (IQ), Emotional Intelligence (EQ), Spiritual Quotient (SQ) and Intelligence Adversety (AQ). Spiritual quotient is type of intelligence needed so that an individual is able to work more effectively. Spiritual quotient allows an individual to think creatively, be visionary, sincere, optimistic as well as able to create or even change the rules; these are the characteristics of qualified employee. Spiritual quotient allows an individual to put his/her behavior and life in broader and richer context. It is the foundation that enables other types of intelligence (Nasution, 2005: 56-57). Zohar and Marshall (2001: 23) stated that spiritual quotient makes an individual feel whole and complete.

This paper aims to investigate if (1) spiritual quotient has any influence towards working performance, (2) spiritual quotient has any influence towards working motivation, (3) working motivation has any influence towards working performance, and (4) spiritual quotient has any influence towards working performance through working motivation simultaneously. 


\section{THEORETICAL FRAMEWORK}

Definition of Spiritual quotient. According to Zohar and Marshall (2007), spiritual quotient (SQ) is a type of intelligence that allows an individual to deal with and overcome any problem related to meaning and value. SQ is the type of intelligence that puts behavior and life in broader and more meaningful context. Furthermore, SQ is physiological entity that helps an individual developing him or herself through some possibilities to apply positive value.

Characteristics of well-developed SQ are 1) a flexible and well-adjusted individuals, 2) caring and considerate, 3 ) ability to deal with pain and disappointment, 4) ability to learn from his/her mistake, 5) ability to realize his/her vision and missions, 6) ability to relate different things, 7) ability to understand meaning of life (Indonesian Wikipedia, retrieved on Nov 4, 2014).

Khavari (2000) defined SQ as non-material indicator or soul of human being. The expert considered $\mathrm{SQ}$ as rough diamond within each individual. An individual should recognize his/her rough diamond, make it shine and use it to reach his/her happiness. Buzan (2003) argued that SQ was one associated with being part of bigger picture / ideas that included «seeing an overall picture».

Therefore, SQ is type of intelligence coming from one's mind; its bases are honesty, open-mindedness, self-knowledge that focuses on the contribution to not only certain religious teaching by building communication based on justice, truth and flexibility that empower an individual holistically.

Working Motivation. Working motivation frequently used in the management is one related to job. Motivation is both instinctive and rational process where an individual is trying to fulfill his/her basic need and personal goals that trigger behavior. (Cole, 2004; Hasibuan, 2003:144). Samsudin (2005) defined motivation as a process that influences or motivates an individual or a group from the outside so that they are willing to carry out particular concept/ plan. Motivation can also be interpreted as an impulse (driving force) that is intended as a natural urge to satisfy and direct one's life.

Robbins (2001) postulated that motivation is the desire or willingness to make an effort to realize goals of an organization, which is conditioned by ability of the effort to fulfill need of an individual. In this case, need is an internal state that causes certain outcome to appear interesting. Need is created when there is no balance between what an individual has and what he/she expects. Motivation is mental power where fulfilling expectation and achieving goals become the orientation. Goal refers to targets or objectives to be achieved by an individual.

Besides those definitions, motivation is individual expectation or drive finalized by selfadjustment (to satisfy motive) that causes an individual to take actions (Mathis and Jackson, 2006; Sperling, 1987; Robbins and Judge, 2007). Furthermore, Robbins (2010) stated that motivation refers to a process where efforts of an individual is given some sort of energy and lead to achievement of certain goals. Motivation has 3 key elements, that is, energy, direction and persistence.

Therefore, motivation in general is drive / willingness that represents various internal and external process of an individual to make continuous effort in order to achieve his/ her goals based on the current situation and condition.

McClelland's theory of motivation that states there are three types of need being earned (instead of being given) that become the main motivators at work are used as the foundation of the study (Robbins, 2010). The three are as follows: need for achievement (n-Ach) that each individual wants to be considered as successful person; need for Power (n-Pow) that refers to need for authority indicated by need to influence other people; need for Affliliation (n-Aff) is real need of an individual as social being despite of his/her status, position at work and occupation.

Furthermore, when an individual wants to have something and it is possible to get it, the individual will make effort to get what he/ she wants. Vroom argued that when there is small chance to achieve his/ her goals, one's motivation is getting low. Vroom's theory of 
expectation has attracted researchers, practitioners and more particularly employees who want to develop their career.

Working Performance. According to Robbins (2001), performance is the accumulated end-result of the entire process and activities of an organization. Based on behavioral approaches in the management, performance is quality and quantity of outcome either in the form of goods or services given by a working individual (Luthans, 2005: 165). Performance is human behavior in an organization that meets the standardized behavior designed to achieve desired results.

In addition, performance is overall outcome or level of success of an individual, in certain period of time, in carrying out his/her duty compared to various possibilities such as standards, result of work, targets or criteria that have been determined in advance and approved within an organization (Rival and Basri, 2005: 50). Furthermore, performance is a comparison between result of work and particular standard (Dessler, 2000: 41). Thus, performance focuses on outcome / result of work. Mangkunagara (2005: 67) stated that performance is result of work in the form of both quality and quantity achieved by an individual in carrying out his/her responsibility.

Based on the elaboration, it can be concluded that performance is the outcome of working process when an individual works based on his/her expertise and skills in the form of either physical or non physical, quality or quantity in certain period of time based on goals of organization. In short, performance is physical and non-physical achievement.

\section{HYPOTHESES DEVELOPMENT}

Influence of Spiritual Quotient (SQ) towards Working Performance. Findings of Trihandini (2005), Wijayanto (2005), Idzapour and Radmehr (2016), Arshad (2015), Rahmasari (2012), and Hidayati (2013)'s studies showed that SQ (Spiritual Quotient) had significant influence towards working performance. Based on the findings, the first hypothesis for the study was:

$\mathrm{H}_{1}$ : Spiritual Quotient (SQ) influences working performance.

Influence of Spiritual Quotient (SQ) towards Working Motivation. Previous studies mentioned SQ (Spiritual Quotient) influenced working motivation for example the studies conducted by Koohbanani (2013), and Sadegifar et al. (2013). Based on the empirical findings, the second hypothesis of the study was:

$\mathrm{H}_{2}$ : Spiritual Quotient (SQ) influences working motivation.

Influence of Working Motivation towards Working Performance. Zehir et al. (2012), Gungor (2011), Noermijati and Primasari (2015), Hayati and Caniago (2012), Arsahdi (2010), Cool (2010) stated that working motivation influenced working performance. Based on the findings, the third hypothesis of the study was:

$\mathrm{H}_{3}$ : Working motivation influences working performance.

Working motivation as Mediating Variables for the Influence of Leadership and Spiritual Quotient (SQ) towards Working Performance. The studies conducted by Koohbanani (2013), and Sadegifar et al. (2013) stated that SQ had influence towards working motivation, while ones conducted by Zehir et al. (2012), Gungor (2011), Noermijati and Primasari (2015), Hayati and Caniago (2012), Arsahdi (2010), Cool (2010) showed that working motivation had influence towards working performance. Based on the findings, the fourth hypothesis was:

$\mathrm{H}_{4}$ : Working motivation is the mediating variable for the influence of spiritual quotient towards working performance.

\section{METHODS OF RESEARCH}

The study was expalanatory research using quantitative approach. The data were obtained using questionnaires of which responses were analyzed using 5-point Likert scale. The samples were 89 employees of the Regional Secretary of Puncak Jaya. The sampling technique was census. The data analysis method was smartPLS that evaluated the direct influence of spiritual quotient towards working performance, the influence of working 
motivation towards working performance, and the influence of spiritual quotient towards working performance through working motivation.

\section{FINDINGS OF RESEARCH}

Description of the Respondents. The respondents were 31 to 35 year-old male staffs whose religion was Christian. They are married, university graduates and have been working in the Regional Secretary of Puncak Jaya for 3 to 6 years.

Means of the variables showed that, based on the respondents' perceptions, leadership had been implemented effectively, Spiritual Quotient (SQ) was at the highest level, working motivation was at the good level and working performance was at the highest level. These information was described in Table 1.

Table 1 - Means of the Variables and Their Indicators

\begin{tabular}{lc}
\hline Indicator & Mean \\
\hline \hline Spiritual quotient & $\frac{3.95}{3.95}$ \\
High Awareness & 3.83 \\
Facing and Taking Advantage of Difficulties & 3.81 \\
Dealing With and Overcoming Pain & 3.91 \\
Quality of Life inspired by Vision and Value & 4.08 \\
Reluctance resulting in Unnecessary Loss & 4.11 \\
Holistic Point of View & 3.78 \\
Initiative for Asking Questions & 4.22 \\
Devotion and Responsibility & 3.87 \\
Working motivation & 3.98 \\
Need for Achievement & 4.03 \\
Need for Affiliation & 3.60 \\
Need for Power & 3.90 \\
Working performance & 3.88 \\
Outcome & 3.83 \\
Time & 3.99 \\
\hline
\end{tabular}

Validity and Reliability. Analysis was conducted by making correlation between score of each item and total score using Pearson-Product Moment correlation technique.The criterion was when correlation coefficient of $r_{x y}$ was higher than 0.3 or the cut off score, the item in the questionnaire was valid. Furthermore, the Alpha Cronbach method was used for reliability testing. Reliability of an instrument is higher when the cronbach alpha coefficient was closer to 1.00 or when cronbach alpha coefficient was higher than 0.60 , the instrument was reliable.

Hypothesis Testing Results. Significance testing was used to test the hypothesis related to the influence of exogenous variables towards endogenous variables. Testing criteria state that when t-statistics $\geq \mathrm{t}$-table (1.96), the exogenous variables had significant influence towards the endogenous variables. The results of the significance were described in Table 2 below.

Tabel 2 - Hypothesis Testing Results for Direct Influence

\begin{tabular}{|c|l|l|l|l|l|l|}
\hline \multicolumn{1}{|c|}{ Exogenous } & \multicolumn{1}{|c|}{ Endogenous } & $\begin{array}{c}\text { Original } \\
\text { Sample (O) }\end{array}$ & $\begin{array}{c}\text { Standard Error } \\
\text { (STERR) }\end{array}$ & $\begin{array}{c}\mathrm{T} \\
\text { Statistics }\end{array}$ & $\begin{array}{c}\mathrm{P} \\
\text { Value }\end{array}$ & \multicolumn{1}{c|}{ Ket } \\
\hline Spiritual quotient & Working Motivation & 0.571 & 0.043 & 13.42 & 0.000 & significant \\
\hline Spiritual quotient & Working performance & 0.017 & 0.05 & 0.334 & 0.369 & $\begin{array}{l}\text { not } \\
\text { significant }\end{array}$ \\
\hline Working Motivation & Working performance & 0.7 & 0.061 & 11.496 & 0.000 & significant \\
\hline
\end{tabular}

The criteria for the indirect effect testing were when t-statistics $\geq \mathrm{t}$-table (1.96) or when probability $\leq$ level of significance (alpha $(\alpha)=5 \%)$, the exogenous variables have significant indirect influence towards the endogenous variables through mediating variable. Table 3 described the hypothesis testing results for the indirect influence. 
Table 3 - Hypothesis Testing Results for Indirect Influence

\begin{tabular}{|c|c|c|c|c|c|c|c|}
\hline Exogenous & Mediating & Endogenous & Indirect Coefficient & SE & T Statistics & P Value & Note \\
\hline Spiritual quotient & Motivation & performance & 0.399 & 0.046 & 8.731 & 0.000 & Significant \\
\hline
\end{tabular}

Based on Table 4, it was found out that there were 3 (three) direct influence of the variables being tested. Meanwhile, based on Table 5, there was one indirect influence being tested. The results of the hypothesis testing were as follows:

$\mathrm{H}_{1}$ : Influence of Spiritual Quotient (SQ) towards Working Performance.

The analysis related to the influence of spiritual quotient towards working performance showed that t-statistics (0.334) was lower than t-tabel (1.96). It meant spiritual quotient (SQ) did not have significant influence towards working performance and therefore, the first hypothesis was rejected. The coefficient, 0.571, was positive which meant SQ (Spiritual Quotient) was directly proportional to working performance. In other words, increasing SQ (Spiritual Quotient) resulted in increasing working performance but the increase was not very significant to increase in SQ (Spiritual Quotient).

$\mathrm{H}_{2}$ : Influence of Spiritual Quotient (SQ) towards Working Motivation.

The analysis related to the influence of $S Q$ (spiritual quotient) towards working motivation showed that t-statistics (13.420) was higher than t- table (1.96). It meant that SQ (spiritual quotient) had significant influence towards working motivation and therefore, the second hypothesis was accepted. The coefficient, 0.571, was positive which meant SQ (Spiritual Quotient) was directly proportional to working motivation. In other words, increasing SQ (Spiritual Quotient) resulted in increasing working motivation.

$\mathrm{H}_{3}$ : Influence of Working Motivation towards Working Performance.

The analysis related to the influence of motivation towards working motivation showed that t-statistics (11.496) was higher than t- table (1.96). It meant that working motivation had significant influence towards working performance and therefore, the third hypothesis was accepted. The coefficient, 0.700 , was positive which meant working motivation was directly proportional to working performance. In other words, increasing working motivation resulted in increasing working performance.

$\mathrm{H}_{4}$ : Working motivation as Mediating Variables for the Influence of Leadership and Spiritual Quotient (SQ) towards Working Performance.

Since SQ (Spiritiual Quotient) did not have significant influence towards working performance but working motivation had significant influence towards working performance, it was concluded that SQ (Spiritiual Quotient) had significant influence towards working performance when working motivation became the medium. Therefore, the fourth hypothesis was accepted. It meant working motivation is the requirement for increase in working performance; thus, working motivation was the full mediation.

\section{DISCUSSION OF RESULTS}

Influence of Spiritual Quotient (SQ) towards Working Performance. Based on the analysis, it was found out that $S Q$ was directly positive yet had no effect towards working performance. In general, the mean score of $S Q$ was good, while the initiative to ask question was the indicator with the lowest mean followed consecutively by the ability to deal with and overcome pain, flexibility, quality of life inspired by vision and value, high awareness, reluctance that resulted in unnecessary loss and holistic point-of-view. Among the eight indicators, institutions/ organizations lead employees to devotion and responsibility. It meant employees felt comfortable with devotion and responsibility. Employees were devoted and responsible towards their duty. As an addition, working performance is at the good level. Therefore, the reasons why SQ (Spiritual Quotient) did not have direct influence towards working performance was employees did not have any initiative to ask questions, unable to deal with or overcome pain, unable to learn from their past mistake, were not flexible, afraid of causing unnecessary loss, and had yet had thorough perception that one thing may lead to another. These aspects had yet become their attention despite of the fact that they were devoted and responsible employees. 
The finding was corroborated to the previous study conducted by Ayranci, (2011) that SQ (Spiritual Quotient) had no influence towards working performance. On the other hands, the findings of the studies conducted by Trihandini, (2005), Hidayati (2013) and Cakraborty (2004) that revealed that SQ (Spiritual Quotient) had influence towards working performance did not support the finding of the study even though the study was the replication of Zohar and Marshall (2001)'s study of which finding was SQ (Spiritual Quotient) was positive but had no influence towards working performance.

Influence of Spiritual Quotient (SQ) towards Working Motivation. The findings of the study showed that Spiritual Quotient (SQ) had positive influence towards working motivation. Based on the results of the hypothesis testing, higher SQ will have positive influence towards working motivation. It meant higher SQ resulted in higher working motivation that involved the need for affiliation, the need for achievement and the need for power. The finding corroborated to the findings of the studies conducted by Sadegifar et al. (2013), and Koohbanani, et al. (2013) that SQ had positive and significant effect towards working motivation.

Individual with high SQ (Spiritual Quotient) will work effectively since religious teaching and beliefs encouraged him or her to carry out his/her duty properly. When the individual felt he could not handle his/her job, he/she would lean on God through prayers.

Influence of Working Motivation towards Working Performance. Based on the results of the hypothesis testing, working motivation had significant influence towards working performance and thus, the third hypothesis was accepted. The evidence was the positive coefficient so it was concluded that motivation was directly proportional towards working performance. It meant employee with higher motivation worked more effectively. The findings corroborated to the findings of the previous study conducted by Hayati and Caniago (2012), Cools (2010), and Gungor (2011) that working motivation had positive influence towards working performance.

Employees' ability to solve problems, responsibility towards their work, risks they took related to their job and feedback they obtained as the result of their performance at work may function as elements to increase their working motivation. Vroom (1964)'s theory of expectation stated that employees would be motivated to carry out their best effort when they believed that these efforts would result in good performance appraisal and it would result in awards such as promotion, increase in salary and other award that may fulfill their expectation.

Working motivation as Mediating Variables for the Influence of Leadership and Spiritual Quotient (SQ) towards Working Performance. The findings showed that spiritual quotient was positive yet did not have any influence towards working performance (the third hypothesis was rejected). It was similar to Ayranci (2011)'s study that SQ (spiritual quotient) had no influence working performance. On the other hands, it did not support the findings of Trihandini (2005), Wijayanto (2005), and Hidayati, 2013's study that SQ (spiritual quotient) influenced working performance. In the study, working motivation had influence towards working performance (the third hypothesis was rejected). The findings corroborated to the previous studies conducted by Cools (2010), Gungor (2011), Hayati and Caniago (2012), which stated working motivation had positive influence towards working performance.

Spiritual quotient did not have direct, significant influence working performance. It happened because the employees were hesitated to cause unnecessary loss, did not have holistic point-of-view, did not have quality of life inspired by vision and value, did not have high awareness, were hesitated to ask questions, had lack of ability to deal with problems and learn from their mistakes although they were devoted and responsible.

Therefore, similar to Latan and Ghozali, (2012) who explained the use of SmartPLS developed by Baron and Kenny (1986), and Hair et. al, (2010), the influence of spiritual quotient $\left(\mathrm{H}_{1}\right)$ towards working performance was not significant, while the influence of working motivation $\left(\mathrm{H}_{2}\right)$ towards working performance was significant; thus, working motivation was the full mediation in mediating the influence of spiritual quotient towards working performance. 
The findings of the study showed that SQ (Spiritual Quotient) was directly positive but it had no influence towards working performance since SQ (Spiritual Quotient) reflected by devotion and responsibility was unable to increase which is represented by productivity and effectiveness at work. The employees were hesitant to ask questions, unable to deal with and overcome difficulties or overcome pain since they had yet had holistic point-of-view. Therefore, it was expected that motivation encouraged the employees to have power for affiliations, achievement as well as power. In other words, employees with high working motivation should be able to meet expectation of institutions where they work in.

\section{CONCLUSION AND SUGGESTIONS}

Based on the findings of a study entitled Working motivation as Mediating Variable for the Influence of Leadership and Spiritual Quotient towards in the Regional Secretary of Puncak Jaya, the conclusions are as follows: spiritual Quotient is directly positive; however, it does not have any influence towards working performance; Spiritual Quotient (SQ) has direct and positive influence towards working motivation; working motivation has direct, positive and significant influence towards working performance; working motivation has role as full mediation for the influence of spiritual quotient towards working performance.

Based on the conclusion, the suggestions given are as follows:

1. In order to maintain and improve working performance, regular training about spiritual quotient is needed to increase one's knowledge and comprehension about spiritual quotient because it is evident that spiritual quotient does not have any influence towards working performance.

2. It is expected that future researchers analyze other variables of spiritual quotient suitable with setting of the study and characteristics of respondents/ subjects of the study.

3. It is expected that future researchers can convince respondents to give accurate information based on the real condition instead of formative response or scientific piece of information.

\section{REFERENCES}

1. Ayranci Evren, 2011. Effects Of Top Turkish Managers' Emotional And Spiritual Intelligences On Their Organizations' Financial Performance, Journal Business Intelligence, Vol.4 No.1.

2. Arshadi, Nasrin (2010), «Basic need satisfaction, work motivation, and job performance in an Industrial company in Iran» Procedia Social and Behavioral Sciences 5 (2010) 1267 $-1272$.

3. Arshad Mahmood, Mohd Anuar Arshad, Adeel Ahmed, Sohail Akhtar, and Zain Rafique (2015), Establishing Linkages between Intelligence, Emotional and Spiritual Quotient on Employees Performance in Government Sector of Pakistan, Mediterranean Journal of Social Sciences MCSER Publishing, Rome-Italy Vol 6 No 6 S2.

4. Buzan, T. (2003). The Power of Spiritual Intellegence: Sepuluh Cara Menjadi Orang Yang Cerdas Secara Spiritual. (Alex Tri Kantjono W and Febrina Fialita.Terjemahan). Jakarta: PT Gramedia Pustaka Utama. Original Version was published in 2001.

5. Chakraborty Shankha. 2004. Endogenous lifetime and economic growth. Journal of Economic Theory 116 (2004) 119-137. Available online at www.sciencedirect.com.

6. Cole, Gerald, 2004. Management Theory and Practice, sixth edition, Thomson, London.

7. Cools K, 2010. The leadership effects of performance measurement and culture organisation compensation on motivation: An empirical study de economic. p.303.

8. Dessler, Gary, 2000. Human Resources Management $10^{\text {th }}$ edition. Prentice Hall. New Jersey.

9. Gibson, James L, 1995, (terj) Organisasi, Perilaku, Struktur and Proses, PT. Erlangga, Jakarta.

10. Gungor, Pinar (2011), The relationship between reward management system and employee performance with the mediating role of motivation: A quantitative study on 
Global Banks, Procedia, Social Behavioral Sciences 24 (2011) 1510-1520. www.sciencedirect.com.

11. Ghozali, Latan. H, 2012: Partial Least SQuares Konsep, Tehnik and Aplikasi Menggunakan Program SmartPLS 2.0 M3 Semarang: Baand Penerbit Universitas Diponegoro

12. Hair, Jr.J.F., Black, W.C., Babin, B.J. and Anderson, R.E. (2010). Multivariant Data Analysis: A Global Perspective. London: Pearson.

13. Hayati, Keumala and Caniago, 2012; Islamic work ethic:The Role of Intrinsic Motivation, Job Satisfaction, Organizational Commitment and Job Performance, Procedia, Social and Behavioral Science 65 (2012) 272-277.

14. Hasibuan, Malayu, S.P. 2003. Manajemen Dasar, Pengertian and Masalah. PT Toko Gunung Agung. Jakarta.

15. Hidayati, Ida Nur, Margono Setiawan and Solimun. 2013. Kecerdasan Emosional and Spiritual quotient Pengaruhnya towards Kepuasan Kerja and Kinerja Karyawan (Studi di Lembaga Penjaminan Mutu Pendidikan (LPMP) Nusa Tenggara Barat) retrieved on March 12, 2015. http://jurnaljam. ub.ac.id. Vol. 11. No.4.

16. Izadpour, Mohammad and Radmehr Iraj. 2016. Effect of Spiritual Intelligent in Corporate Entrepreneurship A Case Study of Isfahan Post Office. International Businness Management 10 (12): 2373-2378. ISSN:1993-5250. Medwell Journals.

17. Khavari, Khalil A, 2000. Spirtual Intelligence: A Practical Guide to Personal Happiness. New Liskeard: White Mountain Publications.

18. Koohbanani Shahin Ebrahimi, Reza Dastjerdi, Taghi Vahidi, Mohammad-Hassan Ghani Far . 2013. The Relationship Between Spiritual Intelligence and Emotional Intelligence with Life Satisfaction Among Birjand Gifted Female High School Students. Procedia Social and Behavioral Sciences 84 (2013) 314 - 320. Available online at www.sciencedirect.com.

19. Luthans, F. 2005. Perilaku Organisasi. Edisi 10. Translated by Vivin Andika. Yuwono et.al. Andi. Yogyakarta.

20. Mangkunegara, Anwar Prabu. 2005. Evaluasi Kinerja. Refika Aditama. Bandung.

21. Mathis Robert and Jacson John H. 2006, Human Recourse Management translated version. Salemba Empat. Jakarta.

22. Mc. Clelland. D. C. 1961. The achieving society. The Free Press. New York.

23. Nasution, Ahmad Taufik. 2005. Metode Menjernihkan Hati; Melejitkan Kecerdasan Emosi and Spiritual Melalui Rukun Iman. PT. Mizan Pustaka. Bandung.

24. Noermijati, and Diana Primasari. (2016) The effect of job stress and job motivation on employees' performance through job satisfaction (A study at PT. Jasa Marga (Persero) Tbk. Surabaya - Gempol branch) Journal of Economics, Business, and Accountancy Ventura Vol. 18, No. 1, August - November 2015, pages 231 - 240

25. Noermijati, 2015. Peran Kepemimpinan Transformasional And Motivasi Towards Kinerja Karyawan Dengan Moderasi Masa Kerja. Jurnal Keuangan and Perbankan, 2(19), pp. 326-335 Terakreditasi SK. No. 040/P/2014 http://jurkubank.wordpress.com

26. Rahmasari, Lisda. 2012. Pengaruh Kecerdasan Intelektual, Kecerdasan Emosi, and Spiritual quotient towards Kinerja Karyawan. Majalah IImiah Informatika 3 (1): 1-20.

27. Rivai, Veithzal and Ahmad Fawzi Mohd Basri, 2005. Performance Appraisal. Cetakan Pertama, PT Raja Grafindo Persada, Jakarta.

28. Robbins Stephane, P (2001); «Basic Motivation Concepts, Organizational Behavior» Prentice Hall, New Jersey, pp 155 - 209, ch.6.

29. Robbins, and Judge, 2007. Perilaku Organisasi, Buku 1 and 2. Jakarta: Salemba Empat.

30. Robbins Stephane, P. 2010. Manajemen Edisi Kesepuluh. Erlangga. Jakarta.

31. Sadeghifar Jamil, Mohammadkarim Bahadori , Donia Baldacchino, Mehdi Raadabadi \& Mehdi Jafari. 2013. Relationship between Career Motivation and Perceived Spiritual Leadership in Health Professional Educators: A Correlational Study in Iran. Global Journal of Health Science; Vol. 6, No. 2; 2014 ISSN 1916-9736 E-ISSN 1916-9744. Published by Canadian Center of Science and Education. 
32. Sappe Syahruddin, Yohanis Rante, Ruben Tuhumena, Bonifasia Elita Bharanti. 2015. Pengaruh Kepemimpinan Towards Working performance Yang dimediasi oleh Budaya Organisasi komitmen Kerja And Working motivation.

33. Sperling Abraham. (1987). Psychology : Made Simple. The Publisher W. H. Allen \& Co. Ltd. London.

34. Taylor, L. 1997. "Linking Environmental Performance to Profitability». Chemical Business, 11: 27-31

35. Trihandini, R.A.F.M. (2005). Analisis Pengaruh Kecerdasan Intelektual, Kecerdasan Emosi, and Spiritual quotient Towards Kinerja Karyawan (Studi Kasus di Hotel Horison Semarang).

36. Zehir, Cemal , Ebru Erdogan. 2011. The Association between Organizational Silence and Ethical Leadership through Employee Performance. Available at www.sciencedirect.com Procedia Social and Behavioral Sciences 24 (2011) 1389-1404 7th.

37. Zohar, Andah and Marshall. Ian (2007). SQ: Spiritual Intelegence - The Ultimate Intellegence. Rahmani Astuti, Ahmad Nadjib Burhani, Ahmad Baiqani (Alih Bahasa). SQ: Keserdasan Spiritual. Jakarta: Mirzan Media Utama ( MMU) 